\title{
RAČUNOVODSTVO U OBLAKU U REPUBLICI HRVATSKOJ
}

\section{Karlo Lukić}

Sveučilište Josipa Jurja Strossmayera u Osijeku,

Ekonomski fakultet u Osijeku, Osijek, Republika Hrvatska

\begin{abstract}
Apstrakt:
Računovodstvo u oblaku označava iskorak tradicionalnog računovodstvenog sustava prema novom sustavu podržanog informacijskom tehnologijom. Prednosti takvog računovodstvenog sustava u usporedbi s klasičnim su mnoge, no postoje i određeni nedostaci. Cilj ovoga rada je istražiti informiranost o korištenju tehnologije računovodstva u oblaku na području Republike Hrvatske te stupanj rizika povjere poslovnih podataka trećim osobama, ponuđačima cloud usluga. Postavljena je hipoteza kako računovođe u Republici Hrvatskoj nisu dovoljno informirani o prednostima računovodstva u oblaku, te o načinu na koji računovodstvo u oblaku može utjecati na poslovanje gospodarskog subjekta. Kako bi se navedena hipoteza potvrdila, provedena je online anketa kojom su ispitani računovođe na prostoru Republike Hrvatske te budući računovođe, studenti Ekonomskog fakulteta na području jednoga grada. Rad završava sa preporukama o povećanju cloud accounting informiranosti na prostorima Hrvatske, Srbije te Bosne i Hercegovine.
\end{abstract}

Ključne reči:

informacijska tehnologija, računalstvo u oblaku, tradicionalno računovodstvo, korisnost, prednosti.

\section{UVOD}

U radu će se objasniti značenje pojma računalstva u oblaku. Zatim će se navedeni koncept pojasniti sa gledišta računovodstvene profesije, pri čemu će se pojam oblaka spojiti sa računovodstvom tvoreći koncept računovodstva u oblaku. Pojam cloud accountinga zatim će se dodatno objasniti, prednosti takvog sustava usporedit će se sa tradicionalnim računovodstvenim sustavom, a moguće poteškoće i rizici analizirati i pojasniti. U svome radu "Primjena računovodstvenih programa u oblaku", Ana Novak i Bojan Zvonar opažaju (2015, p. 28): "U Republici Hrvatskoj, prema stavovima autora, nisu provedena relevantna istraživanja o primjeni računovodstvenih rješenja u oblaku”, stoga će ovaj rad pokušati pružiti odgovor na navedenu tvrdnju.

\section{RAČUNALSTVO U OBLAKU}

U svome radu Digitalizacija Poslovanja, Neven Miličević i Sanela Agačević (2015, p. 186) objašnjavaju: "Digitalizacija je proces pretvaranja analognog signala u digitalni oblik. Moguće je digitalizirati sve vrste gradiva, od teksta, audio i videozapisa do trodimenzionalnih objekata." Korištenje digitalizacije uveliko je pridonjelo razvoju nove ekonomije u kojoj je informacijska tehnologija norma poslovanja. Još je jučer ta ideja bila pretočena softverskim paketom koji se nalazio na računalu poslovnog korisnika, a već danas ona se nalazi u novom konceptu; korisnik softverskom paketu pristupa sa udaljene lokacije, iz drugoga mjesta, grada ili države. 
Računalstvo u oblaku ${ }^{1}$ jednostavno predstavlja računalstvo koje za svoje ključne funkcije koristi internetsku povezanost. U svome radu "Primjena cloud computinga u računovodstvu”, autori Mirko Savić i Siniša Janković (2015, p. 1) navode kako se "danas pojam "cloud" izjednačava sa dostupnošću, lakoćom i brzinom upravljanja podacima." Najbliže terminu općeprihvaćene definicije međutim, smatra se ona Nacionalnog instituta za standarde i tehnologiju (NIST), Sjedinjenih Američkih Država (Mell \& Grance, 2011, p. 2), pri čemu se cloud computing definira kao "model koji omogućuje pogodan pristup "po zahtjevu" mreži zajedničke grupe podesivih računalnih resursa (npr. mreža, servera, skladištenja, aplikacija i usluga) koji se korisniku mogu dostaviti brzo uz minimalan napor upravljanja ili interakcije sa davateljem usluge."

Iz navedenih definicija moguće je odrediti tri ključna pojma koja predstavljaju oblak: računalni resursi, računalna oprema i internetska povezanost koja omogućuje sve ostale procese. Dimitriu i Matei $(2015$, p. 1) sa Al. Ioan Cuza Sveučilišta u Iasi, opažaju da je "u samo nekoliko godina, internet postao opsežan proizvod, sredstvo koje si svatko može priuštiti”. Tome u prilog ide i istraživanje Eurostata iz 2014. godine (Giannakouris \& Smihily, 2014) navodeći da je pristup internetu omogućen u gotovo svim poduzećima (97\%) unutar Europske unije pri čemu je udio poduzeća sa pristupom internetu bio znatno visok, no ipak je samo dio (1/5) koristio usluge oblaka. Novak i Zvonar $(2015$, p. 27) pojašnjavaju situaciju na prostoru Hrvatske: "Republika Hrvatska se u 2014. godini nalazila u prosjeku Europske unije, kako po broju poduzeća koja su imala pristup internetu (96\%), tako i po broju poduzeća koja su koristila usluge računalstva u oblaku." Usporedbe radi, na prostoru Crne Gore nešto manji postotak gospodarskih subjekata (12.5\%) koristi i plaća usluge clouda (Zavod za Statistiku, 2014), dok unutar granica Republike Srbije samo 3.8\% poduzeća koristi oblak (Republički Zavod za Statistiku, 2015). S druge strane svijeta, postotak korištenja poslovnih rješenja u oblaku raste te je u 2014. godini čak $73 \%$ ispitanika u SAD-u navelo korištenje nekog od rješenja u oblaku (The Cloud Accounting Institute, 2014).

\section{Računovodstvo u oblaku}

Cilj svakog računovodstvenog sustava je prikupljanje i pohranjivanje podataka o aktivnostima i transakcijama, zatim procesiranje tih podataka u informacije koje su korisne pri donošenju odluka i na kraju provođenje adekvatne kontrole za zaštitu organizacijske imovine (Ebenezer et al., 2014). Stoga, nije teško za zaključiti kako se koristi računalstva u oblaku mogu lako primjeniti na računovodstvenu profesiju.

1 U radu su korišteni sinonimi: oblak, cloud i računalstvo u oblaku
Usporedba tradicionalnog računovodstva i računovodstva u oblaku

Ključna razlika tradicionalnog računovodstva i računovodstva u oblaku ${ }^{2}$ je internetska povezanost. U nastavku, Christauskas i Miseviciene (2012) predočavaju glavne razlike između tradicionalnih računovodstvenih programa i cloud računovodstvenih rješenja prikazanih u tablici 3.

Tablica 1. Razlike tradicionalnog računovodstva i cloud računovodstva

\begin{tabular}{lll}
\hline & \multicolumn{1}{c}{$\begin{array}{c}\text { Tradicionalni } \\
\text { softver }\end{array}$} & \multicolumn{1}{c}{$\begin{array}{c}\text { Računovodstvo } \\
\text { u oblaku }\end{array}$} \\
\hline $\begin{array}{l}\text { Licenca raču- } \\
\text { novodstvenog } \\
\text { softvera }\end{array}$ & $\begin{array}{l}\text { Kompanija je } \\
\text { vlasnik }\end{array}$ & $\begin{array}{l}\text { Kompanija je } \\
\text { najmoprimac }\end{array}$ \\
\hline $\begin{array}{l}\text { Lokacija } \\
\text { sustava }\end{array}$ & $\begin{array}{l}\text { Odabrana od strane } \\
\text { kompanije }\end{array}$ & Oblak \\
\hline Hadrver & $\begin{array}{l}\text { Priskrbljen od } \\
\text { strane kompanije }\end{array}$ & Uključen \\
\hline $\begin{array}{l}\text { Windows \& } \\
\text { SQL Server }\end{array}$ & $\begin{array}{l}\text { Priskrbljen od } \\
\text { strane kompanije }\end{array}$ & Uključen \\
\hline $\begin{array}{l}\text { Trošak } \\
\text { održavanja }\end{array}$ & Odvojen & Uključen \\
\hline $\begin{array}{l}\text { IT sredstva } \\
\text { Priskrbljena od } \\
\text { strane kompanije ili } \\
\text { eksternalizirana }\end{array}$ & Nisu potrebna \\
\hline Broj korka & $\begin{array}{l}\text { Dana od strane } \\
\text { treće osobe }\end{array}$ & $\begin{array}{l}\text { Dana od strane } \\
\text { treće osobe }\end{array}$ \\
\hline
\end{tabular}

Izvor: Christauskas \& Miseviciene (2012, p. 17)

Iz tablice 3. vidljive su razlike računovodstva u oblaku naspram tradicionalnog računovodstva u pogledu vlasništva nad licencom, lokacije sustava, hadrvera, servera, troška održavanja, potrebnih IT sredstava i broja mogućih korisnika.

\section{Prednosti računovodstva u oblaku}

Glavne prednosti računovodstva u oblaku nad tradicinalnim računovodstvom su: niži inicijalni troškovi kapitalnih ulaganja, pristupačnost i fleksibilnost sustava, brzina i način obrade podataka, usklađenost sustava, jednostavnost i efikasnost, smanjenje rizika od uništenja podataka i općenita sigurnost sustava ${ }^{3}$. Marković (2014, p. 676) navodi da "premještanje poslovanja na cloud omogućava računovođama da rade sa bilo kojeg mjesta u bilo koje vrijeme. To je način da se smanje troškovi, poboljša efikasnost i podaci učine pristupačnijima." Navedene prednosti prikazane su u tablici 4.

2 U radu su korišteni sinonimi: računovodstvo u oblaku i cloud accounting.

3 Može se promatrati sa oba aspekta: prednosti i nedostatka oblaka. 
Tablica 2. Prednosti računovodstva u oblaku nad tradicionalnim računovodstvom

\begin{tabular}{ll}
\hline Prednosti & \multicolumn{1}{c}{ Opis } \\
\hline $\begin{array}{l}\text { Niži } \\
\text { troškovi }\end{array}$ & $\begin{array}{l}\text { niži troškovi hardvera i softvera, upravljanje mre- } \\
\text { poduzeća plaćaju mjesčnu pretplatu samo za odre- } \\
\text { den broj korisnika usluga }\end{array}$ \\
\hline Sigurnost & $\begin{array}{l}\text { većina poslužitelja aplikacija u oblaku nudi visoku } \\
\text { mrežno bazirani sustavi su zapravo jednako sigurni } \\
\text { ili čak i sigurniji te imaju jednake ili bolje interne }\end{array}$ \\
\hline $\begin{array}{l}\text { kontrole od sličnih lokalnih softvera } \\
\text { Prilago- } \\
\text { đenost po- } \\
\text { slovanju }\end{array}$ & $\begin{array}{l}\text { dodavanje novih softvera je vrlo jednostavno } \\
\text { poslužitelj češće nadograđuje aplikacije nego što si to } \\
\text { poduzeća mogu brzo pristupiti potrebnim resursima } \\
\text { ako to zahtjeva proširenje poslovanja }\end{array}$ \\
\hline
\end{tabular}

$\begin{array}{ll}\text { Jednostav- } & \begin{array}{l}\text { za pristup računovodstvu potreban je samo mrežni } \\ \text { pristup }\end{array} \\ \text { na admi- } & \begin{array}{l}\text { svi korisnici imaju istu inačicu softvera } \\ \text { nistracija }\end{array} \\ & \text { omogućuje backup podataka u realnom vremenu }\end{array}$

Usklađe- usklađenost s mnoštvom zahtjeva, uključujući računost novodstvene standarde i interne kontrole

zaposlenici, partneri i klijenti mogu pristupiti i ažuPristup rirati informacije gdje god se nalazili, nema potrebe za vraćanjem na radno mjesto

Probno pružatelji usluge često omogućuju besplatno probno korištenje korištenje i opširne demo verzije što omogućuje testiranje prikladnosti aplikacije

Izvor: Christauskas \& Miseviciene (2012, p. 15)

Vidljivo iz tablice, incijalni troškovi tiču se troškova hardvera i softvera koji su u ovom slučaju znatno niži od tradicionalnog softverskog paketa. Sigurnost oblaka predstavlja prednost na temelju interne kontrole, visoke razine sigurnosti koja je ponuđena od većine poslužitelja aplikacija te backupa sustava koji omogućuje dodatno pohranjivanje podataka. Prilagođenost poslovanju podrazumijeva dodavanje novih softvera, nadogradnje postojećih verzija aplikacija i dostupnost podataka u stvarnom vremenu. Računalstvo u oblaku omogućuje jednostavniju administraciju jer za svoje potrebe koristi internet dok svi korisnici imaju istu verziju aplikacije kojoj pristupaju u real timeu pri čemu se također poboljšava i kolaboracija između zaposlenika (Savić \& Janković, 2015). Usklađenost sustava odnosi se na računovodstvene standarde i interne kontrole uz koje je cloud accounting u skladu, dok pristup oblaku znači pristupačnost sa bilo koje lokacije na svijetu uz prethodnu potrebu internetske povezanosti. $\mathrm{Na}$ kraju, probno korištenje predstavlja dodatnu prednost jer omogućuje testiranje radnog programa u stvarnom okruženju na temelju čega korisnik odlučuje hoće li se pretplatiti na potpunu verziju računovodstvenog programa ili je odbaciti.

\section{Nedostaci računovodstva u oblaku}

Brojne prednosti računovodstva u oblaku neizbježno dolaze uz određenu cijenu. Cijenu u slučaju računovodstvenog oblaka predstavljaju rizici od sigurnosti i dostupnosti podataka na mreži. Kinkela (2013, p. 2) navodi: "Prvi značajni problem s kojim se suočavaju oni koji prihvaćaju cloud tehnologiju leži u činjenici da pristup povjerljivim informacijama od strane davatelja usluge zahtjeva pregled sigurnosnih politika i osiguranja od odgovornosti pružatelja usluge u slučaju povrede sigurnosti sustava. Drugi problem tiče se činjenice da u slučaju zakazivanja programa na oblaku, klijentu nije omogućen pristup ili prilika otklanjanja problema na oblaku." $S$ navedenom tvrdnjom slaže se i Novak (2015) te uz probleme sigurnosti i dostupnosti podataka napominje i važnost dobre internetske veze koja je poduzećima prijeko potrebna za svakodnevni pristup poslovanju kao i potencijalni problem ovisnosti o pružatelju usluge i njegovim aplikacijama na clou$d u$. Sukladno tome, Christauskas i Miseviciene (2012) navode četiri rizika cloud tehnologije, prikazanih u tablici 5 .

Tablica 3. Rizici cloud računalstva u poslovanju

$$
\text { Rizici Objašnjenje i karakteristike }
$$

Sigurnosni

rizik $^{*}$

tiče se problema sigurnosti i povjerljivosti informacija

Slaba internetska povezanost

neophodna za pristup podacima na oblaku

Gubitak

odgovornost pružatelja usluge da sustav

kontrole održava u slučaju prestanka rada ili kvara te da se izvršava ažuriranje i svakodnevno upravljanje aplikacije na cloudu

Ovisnost

kompanija postaje ovisna o računovodstvenom rješenju u oblaku jednako kao i o pružatelju usluge clouda

${ }^{*}$ Nedavno zabilježeni primjer provale sigurnosnog sustava poduzetnika iz Varaždina (Večernji List, 2016) od kojega je traženo 16.000 kuna radi dekodiranja datoteka na mreži, može se smatrati navedenim rizikom.

Izvor: Christauskas \& Miseviciene (2012, p. 15)

Kao što je iz tablice vidljivo, četiri potencijalna rizika predstavljaju: sigurnost, internetska povezanost, kontrola i ovisnost o pružatelju usluge računalstva u oblaku. O problemima oblaka u susjednoj Bosni i Hercegovini, Savić i Janković (2015, p. 722) navode: "S obzirom da je računovodstvo direktno povezano sa upravljanjem novcem, a u cloud computingu se sve informacije nalaze na serverima koji nisu u vlasništvu poduzeća, postoji visoka razina zabrinutosti za sigurnost informacija. Istraživanje koje smo proveli pokazalo je da menadžeri identificiraju ovaj problem kao glavni kada je u pitanju korištenje cloud computing tehnologije. Također, smanjenje kontrole nad računovodstvenim softverom, kojim u potpunosti upravlja provider, prepoznato je kao jedan 
od značajnih problema." Isti autori (Savić \& Janković, 2015) opažaju da su nedovoljna kvaliteta komunikacijske infrastrukture, komplikacije zakonske regulative te nepovjerenje i neinformiranost gospodarskih subjekata, jedni od glavnih razloga nedovoljne primjene cloud computing tehnologije na području Bosne i Hercegovine te kao potrebna rješenja navode dodatnu edukaciju i zakonsku usklađenost unutar zemlje. Sukladno istraživanju u Bosni i Hercegovini, Vićentijević (2015) navodi istraživanje provedeno u Republici Srbiji o upotrebi cloud računovodstva u odnosu na tradicinalno računovodstvo koje je pružilo jednak zaključak; na području Republike Srbije potrebno je povećati informiranost o cloud računovodstvu. Na prostoru Republike Hrvatske nailazi se na jednak problem. Marija Kušić (Valpovština Info, 2016), vlasnica računovodstvenog servisa ARIOS iz Belišća opaža: "Agencija ARIOS već sada može imati ured bez papira, no problem su naši klijenti koji nemaju informatičku opremu i nisu dovoljno informatički obrazovani, pa s njima ne možemo raditi online." Na temelju navedenog, lako je zaključiti da je problem neinformiranosti i obrazovanja uvelike prisutan na sva tri područja. Dimitriu i Matei (2015, p. 730) objašnjavaju: "Kao i svaka nova paradigma, cloud računovodstvo se također suočava sa brojnim poteškoćama. Nedostatak znanja i strah od nepoznatog možda su najznačajnije teškoće pri usvajanju cloud aplikacija."

\section{RAČUNOVODSTVO U OBLAKU U REPUBLICI HRVATSKOJ}

Uzimajući u obzir prethodna istraživanja na području Bosne i Hercegovine te Srbije i Crne Gore, pretpostavka je da računovodstvo u oblaku na prostoru Republike Hrvatske nailazi na jednake poteškoće. Cilj ovoga rada pritom je provjeriti informiranost o računovodstvu u oblaku te sigurnosnom riziku kojem su korisnici cloud usluga izloženi. Postavljena je hipoteza kako trenutni i budući računovođe (studenti) nisu dovoljno upoznati sa prednostima računovodstva u oblaku.

\section{Metodologija istraživanja}

Istraživanje je provedeno na području Republike Hrvatske metodom anketiranja, pri čemu je online anketa prethodno kreirana putem servisa "Typeform". Anketa je potom proslijeđena na email adrese računovođa predstavnika hrvatskih udruga računovodstva i financija, članica "Hrvatske zajednice računovođa i financijskih djelatnika" te budućih studenata računovođa Ekonomskog fakulteta, smjera financijski menadžment na području jednoga grada. U anketi je ukupno sudjelovalo 100 ispitanika, koje su činili 53 računovođa i 47 studenata. Postavljena su 4. pitanja na temelju istraživanja "Upotreba cloud računovodstva u odnosu na tradicionalno računovodstvo u Republici Srbiji” (Petrović et al., 2014) te "Primjena cloud computinga u računovodstvu" (Savić \& Janković, 2015), a koja su slijedom glasila:

1. Koliko ste upoznati sa konceptom "clouda"?

2. Jeste li ikada koristili usluge "clouda"?

3. Jeste li upoznati sa konceptom "cloud" računovodstva?

4. Ukoliko biste radili u "cloud" računovodstvu, bi li povjerili čuvanje svojih poslovnih podataka i programa trećim osobama, na serveru za koji ne znate gdje se točno nalazi?

Dobiveni rezultati istraživanja prikazani su u nastavku rada.

\section{Rezultati i analiza istraživanja}

Prema prethodnom istraživanju, prvo anketirano pitanje odnosilo se na upoznatost studenata i računovođa sa konceptom računalstva u oblaku. Ispitanici su u mogućnosti bili pružiti skalarni odgovor od 0 do 5 , pri čemu je broj 0 predstavljao potpunu neupoznatost sa oblakom, a broj 5 potpunu upoznatost sa konceptom clouda. Dobiveni rezultati prikazani su na grafikonu 1.

Upoznatost konceptom clouda na području Republike Hrvatske

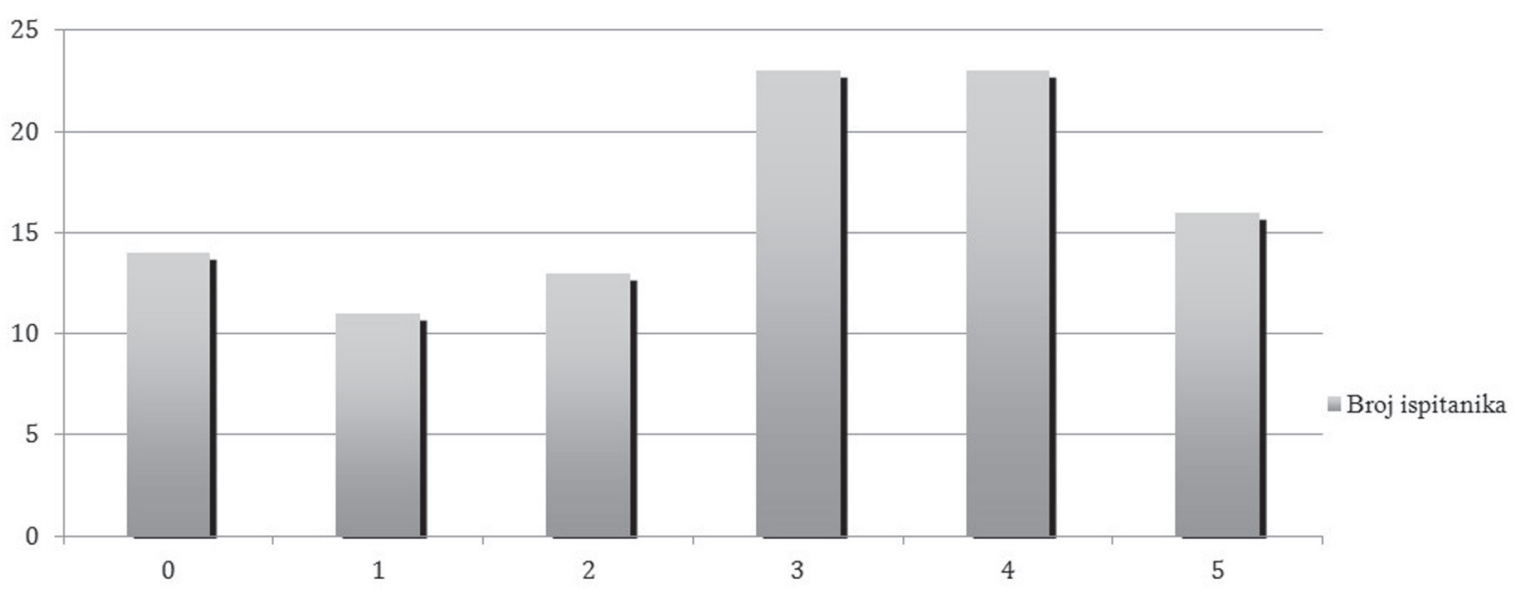


Vidljivo iz grafikona 1., najveći broj ispitanika (23) odgovorilo je da dobro (3) i vrlo dobro upoznato (4) konceptom clouda. Dobru upoznatost slijedi potpuna upoznatost (5) 16 ispitanika te neupoznatost (0) od strane 14 ispitanika, dok je 13 ispitanika dovoljno upoznato (2) konceptom računarstva u oblaku. Najmanji broj ispitanika (11) nedovoljno je upoznato (1) konceptom clouda. Prosječni odgovor na 1. anketirano pitanje pritom je 2.78, pri čemu je sigurno zaključiti da je na prostoru Republike Hrvatske informiranost o računalstvu u oblaku dovoljno dobra.

Drugo anketirano pitanje odnosilo se na pratičnu dimenziju korištenja usluga oblaka. Pitanjem "Jeste li ikada koristili usluge clouda?" provjerila se sigurnost ranije korištenosti usluge računalstva u oblaku. Rezultati ispitanika prikazani su u tablici 6 . unutar Republike Hrvatske nije dobro upoznata konceptom računovodstva u oblaku.

Posljednje anketirano pitanje pružilo je odgovor na način kako ispitanici doživljavaju oblak po pitanjima sigurnosti i rizika. Rezultati su vidljivi na grafikonu 2.
Tablica 4. Sigurnost ranije korištenosti cloud usluga na području Republike Hrvatske

\begin{tabular}{ccc}
\hline Odgovori & $\begin{array}{c}\text { Broj } \\
\text { odgovora }\end{array}$ & $\begin{array}{c}\text { Postotak } \\
\text { odgovora }\end{array}$ \\
\hline $\mathrm{Da}$ & 51 & $51 \%$ \\
\hline $\mathrm{Ne}$ & 35 & $35 \%$ \\
\hline $\begin{array}{c}\text { Možda, nisam } \\
\text { siguran/na }\end{array}$ & 14 & $14 \%$ \\
\hline
\end{tabular}

Kao što je vidljivo iz tablice 6., većina ispitanika (51) potpuno je sigurna da je ranije koristila usluge oblaka. Najmanji broj ispitanika (14) nije sigurno je li koristio cloud usluge dok je središnji dio ispitanika (35\%) potpuno siguran da nikada nije koristio usluge računarstva u oblaku. Posljednja dvije tvrdnje pritom su kontradiktorne jer se sama činjenica ispunjavanja online ankete i način dobivanja odgovora ${ }^{4}$ od ispitanika može smatrati korištenjem rješenja u oblaku te nedovoljnog poznavanja tehnologije od strane navedene dvije grupe ispitanika.

Treće pitanje online ankete kao cilj imalo je pružiti točan i precizan pogled na informiranost trenutnih i budućih računovođa o računovodstvu u oblaku. Pritom je 31 ispitanik potpuno neupoznat (0) konceptom cloud računovodstva, kojega slijedi djelomična ili dobra upoznatost (3) 25 ispitanika. Najmanji broj ispitanika (7) potpuno je upoznat (5) konceptom računovodstva u oblaku dok je prosječni odgovor svih ispitanika iznosio 1.95, što se može protumačiti kao dovoljna upoznatost spajanja koncepata oblaka i računovodstva. U skladu $s$ rezultatima prvog anketiranog pitanja o upoznatosti cloud tehnologije općenito, pri čemu je većina ispitanika potvrdno odgovorila da je dobro upoznata sa općenitom tehnlogijom rješenja u oblaku, većina trenutnih i budućih računovođa

4 Pod time se misli na online uslugu kreiranja ankete koja je u vlasništvu ponuđača cloud usluge.
Ukoliko biste radili u "cloud" računovodstvu, bi li povjerili čuvanje svojih poslovnih podataka i programa trećim osobama, na serveru za koji ne znate gdje se točno nalazi?

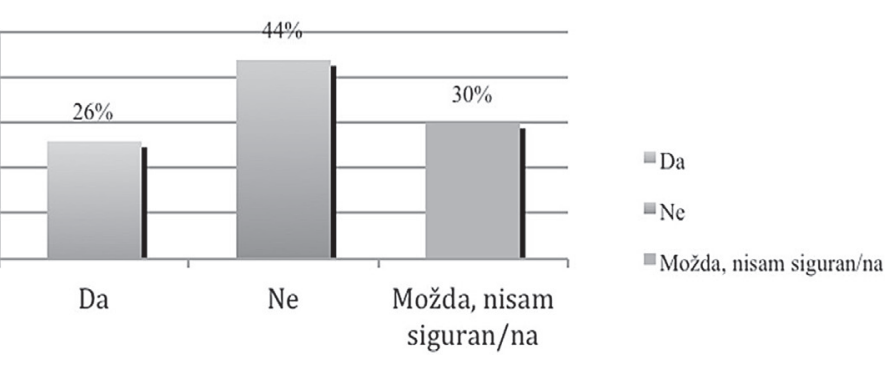

siguran/na

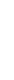

Iz grafikona 2. vidljiv je stupanj povjerenja u računovodstvo u oblaku na području Republike Hrvatske. Većina ispitanika (44\%) nikada ne bi povjerila svoje poslovne podatke trećim osobama na serveru za koje ne zna gdje se točno nalazi, dok bi manji postotak od $26 \%$ to bio spreman učiniti, no ipak veći dio ispitanika (30\%) ostaje skeptično i neodlučno pri povjerenju podataka ponuđačima cloud usluga. Nizak postotak povjerenja u cloud accounting na području Republike Hrvatske razumljiv je ako se uzmu u obzir rezultati prethodnih pitanja o neinformiranosti budućih i trenutnih računovođa o cloudu i računovodstvu u oblaku, stoga je za pretpostaviti da će ispitanici biti skeptični prema tehnologiji koju u potpunosti ne razumiju.

\section{ZAKLJUČAK}

Rizici do kojih korištenje cloud tehnologije može dovesti najčešće su prisutni u dimenzijama povjerljivosti, dostupnosti ili nedostatku informacija o samoj tehnologiji računalstva u oblaku. Provedeno istraživanje dokazalo je da trenutni i budući računovođe u Republici Hrvatskoj nisu dovoljno upoznati cloud accounting tehnologijom, iako je općenita informiranost o cloud tehnologiji dovoljno dobra. Kao i na prostorima Bosne i Hercegovine (Savić \& Janković, 2015) te Srbije (Vićentijević et al., 2015), poteškoće se prvenstveno nalaze u problemima nedovoljne informiranosti o računovodstvu u oblaku te sigurnosnom riziku povjere poslovnih podataka trećim osobama, ponuđačima cloud poslovnih rješenja. Posljednji od navedenih problema, može se promatrati i kroz prizmu rizika od ovisnosti o ponuđaču usluge (Christauskas \& Miseviciene, 2012). Postavljena je hipoteza kako trenutni i budući računovođe na prostoru Republike Hrvatske nisu dovoljno upoznati tehnologijom računovodstva u oblaku te je ista potvrđena provedenom online anketom. Anketa je potvrdila da je i povjerenje u cloud sustav na prostoru Republike 
Hrvatske relativno nisko (44\%) te da isto predstavlja poslovni rizik sa kojim se većina ispitanika ne bi suočila. Kao moguća rješenja navedenih poteškoća, preporučuju se dodatne edukacije i obrazovanje o uslugama računovodstva u oblaku i općenitog načina na koji cloud accounting funkcionira i poboljšava poslovanje gospodarskog subjekta. Navedene mjere povećale bi sigurnost o načinima rada i vrstama usluga računovodstva u oblaku, pri čemu bi se povjerenje u ponuđače tih usluga zasigurno povisilo.

\section{LITERATURA}

ACCA - IMA Report. (2013). Digital Darwinism: thriving in the face of technology change. Accountancy futures academy. 1-61. Retrieved August 05, 2016, from http://www.accaglobal.com/content/dam/acca/global/PDF-technical/futures/polafa-tt2.pdf.

Armbrust, M., Fox, A., Griffith, R., Joseph, A.D., Konwinski, A., Lee, G., Rabkin, A., Stoica, I., \& Zaharia, M. (2010). A view of cloud computing [Electronic version]. Communication of the ACM. 53(4). 50-58. Retrieved August 15, 2016, from http:// delivery.acm.org/10.1145/1730000/1721672/p50-armbrust. pdf?ip $=83.85 .216 .148 \& \mathrm{id}=1721672 \& \mathrm{acc}=\mathrm{OPEN} \& \mathrm{key}=4 \mathrm{D} 4$ 702B0C3E38B35\%2E4D4702B0C3E38B35\%2E4D4702B0C3 $\mathrm{E} 38 \mathrm{~B} 35 \% 2 \mathrm{E} 6 \mathrm{D} 218144511 \mathrm{~F} 3437 \& \mathrm{CFID}=833995055 \& \mathrm{CFTO}$ $\mathrm{KEN}=18247789 \& \_\mathrm{acm} \_=1473003268 \_5 \mathrm{a} 0 \mathrm{c} 8 \mathrm{f} 003 \mathrm{a} 05 \mathrm{fba} 6$ 341527aea292e7e1. DOI: 10.1145/1721654.1721672.

Boomer J. (2013). The Benefits and Challenges of Cloud Accounting. CPA Practice Advisor. Retrieved August 25, 2016, from http://www.cpapracticeadvisor.com/article/11074737/thebenefits-and-challenges-of-cloud-accounting.

Capgemini, Sogeti, \& HP Software (2016). World Quality Report 2015-16. Retrieved August 20, 2016, from https:// www.capgemini.com/thought-leadership/world-qualityreport-2015-16.

$\mathrm{CCH}$ (2013). Cloud computing - a matter of survival for the accounting industry? A national research study commissioned by CCH. 1-11. Retrieved August 25, 2016, from https://www. cch.com.au/DocLibrary/CCH-Research-2013-Cloud-computing-a-matter-of-survival-for-the-accounting-industry. pdf.

Chan, W., Leung, E., Pili, H., \& Crowe Horwath LLP (2012). Enterprise Risk Management for Cloud Computing. Thought Leadership in ERM. 1-23. Retrieved August 05, 2016, from http://www.coso.org/documents/Cloud\%20Computing\%20 Thought\%20Paper.pdf.

Chinyao L., Yahsueh C., \& Mingchang, W. (2011). Understanding the determinants of cloud computing adoption [Electronic version]. Industrial Management \& Data Systems. 1006-1023. Retrieved August 15, 2016, from https://pdfs. semanticscholar.org/665b/3151b324c59582ef2da0f11b1423 712692d1.pdf.

Christauskas, C., \& Miseviciene, R. (2012). Cloud-Computing Based Accounting for Small to Medium Sized Business. Engineering Economics, 23(1), 14-21. DOI: 10.5755/j01. ee.23.1.1220.

Deloitte. (2010). What Cloud Computing Means for Business, and how to capitalize on it. A balancing act. 1-9. Retrieved
August 25, 2016, from https://deloittesa.files.wordpress. com/2010/09/a-balancing-act-what-cloud-computingmeans-for-business1.pdf.

Dimitriu, O., \& Matei, M. (2014). A New Paradigm for Accounting through Cloud Computing. In: Procedia Economics and Finance, Emerging Markets Queries in Finance and Business (EMQ 2013), 24-27 October 2013 (pp. 840-846). TirguMures, Romania: Curran Associates, Inc. Retrieved August 20, 2016, from http://ac.els-cdn.com/S2212567114005413/1s2.0-S2212567114005413-main.pdf?_tid=15d21d32-79e911e6-9039-00000aab0f6c\&acdnat $=1473795448 \_6 a a b 83327$ f8c9017a4bb4b62ec106fce.

Dimitriu, O., \& Matei, M. (2015). Cloud Accounting: A New Player in the Economic Context [Electronic version]. Economy and Management. CC13. 727-732. Retrieved August 15, 2016, from http://upm.ro/cci3/CCI-03/Eco/Eco\%2003\%2080.pdf.

Državni zavod za statistiku Republike Hrvatske. (2015). Statističke informacije. 1-99. Retrieved August 15, 2016, from http:// www.dzs.hr/Hrv_Eng/StatInfo/pdf/StatInfo2015.pdf.

Ebenezer, E.E.S., Omane-Antwi, K.B., \& Kyei, M.E. (2014). Accounting in the Cloud: How Cloud Computing Can Transform Business (The Ghanaian Perspective). In: Proceedings of the Second International Conference on Global Business, Economics, Finance and Social Sciences (GB14 Chennai Conference), 11-13 July 2014 (pp. 1-11). Chennai, India. Retrieved August 22, 2016, from http://globalbizresearch. org/chennai_conference/pdf/pdf/ID_CF440_Formatted.pdf.

Egeland, B. (2009). What Does Cloud Computing Mean to Your Small Business. Cloud Computing and the Small Business. Real Deal Technologies. Retrieved August 25, 2016, from http://www.realdealtechnologies.com/blog/cloud-computing-and-the-small-business/.

Expert Group Report. (2012). Advances in Clouds. Research in Future Cloud Computing. Public version 1.0. European Commision. Information Society and Media. 1-75. Retrieved August 17, 2016, from http://cordis.europa.eu/fp7/ict/ssai/docs/ future-cc-2may-finalreport-experts.pdf.

Giannakouris, K., \& Smihily M. (2014). Cloud computing - statistics on the use by enterprises. Eurostat Statistics Explained. Retrieved August 25, 2016, from http://ec.europa.eu/eurostat/ statistics-explained/index.php/Cloud_computing_-_statistics_on_the_use_by_enterprises.

Ionescu, B., Ionescu, I., Bendovschi, A., \& Tudoran, L. (2013). Traditional Accounting vs. Cloud Accounting [Electronic version]. In: Proceedings of the 8th International Conference Accounting and Management Information Systems (AMIS 2013), 12-13 June 2013 (pp. 106-125). Bucharest, Romania. Retrieved August 16, 2016, from https:/www. researchgate.net/publication/267751382_TRADITIONAL_ACCOUNTING_VS_CLOUD_ACCOUNTING. DOI: 10.13140/2.1.2092.8961.

Isaacson, W. (2011). Steve Jobs. New York: Simon \& Schuster. Retrieved August 15, 2016, from https://vk.com/doc29562313_24415570?dl=52fee1570a50bd4e22.

Kinkela, K. (2013). Practical and ethical considerations on the use of cloud computing in accounting [Electronic version]. Journal of Finance and Accountancy. Iona College. 1-8. Retrieved August 22, 2016, from http://www.aabri.com/manuscripts/131534.pdf. 
Marković, D.S., Branović, I., Popović, R., Zivković, D., \& Tomasević, V. (2014). Review of Cloud Computing in Business. In: Synthesis 2014 - Impact of the Internet on Business Activities in Serbia and Worldwide, 25-26 March 2014 (pp. 673-677). Belgrade, Serbia: Singidunum University, Belgrade, Danijelova 32 Belgrade Serbia. Retrieved August 25, 2016, from http://bib.irb.hr/datoteka/783662.Sinteza-2014. pdf\#page=691. DOI: 10.15308/SInteZa-2014-673-677.

Mell, P., Grance, T., \& National Institute of Standards and Technology - NIST (2011). The NIST Definition of Cloud Computing, Recommendations of the National Institute of Standards and Technology. NIST Special Publication 800-145. 1-3. Retrieved August 15, 2016, from http://nvlpubs.nist.gov/nistpubs/Legacy/SP/nistspecialpublication800-145.pdf.

Miličević, N., \& Agačević, S. (2015). Digitalizacija poslovanja. Računovodstvo, revizija i financije (RriF). 15(4). 185-187.

Molnar, D., Scechter, S., \& Microsoft Research (2010). Self Hosting vs. Cloud Hosting: Accounting for the security impact of hosting in the cloud. In: Proceedings of the Ninth Workshop on the Economics of Information Security (WEIS), 7-8 June 2010 (pp. 1-15). Harvard University, Cambridge, MA, USA: Harvard University. Retrieved August 23, 2016, from http://www.econinfosec.org/archive/weis2010/papers/session5/weis2010_schechter.pdf.

Novak, A., \& Zvonar, B. (2015). Primjena računovodstvenih programa u oblaku. Računovodstvo i financije. 15(8). 25-28.

Petrović, Z., Vićentijević, K., Stefanović, D., \& Stanić, N. (2014). Savremeni oblici nematerijalnih ulaganja u eri informacionih tehnologija. In: Synthesis 2014 - Impact of the Internet on Business Activities in Serbia and Worldwide, 25-26 March 2014 (pp. 559-563). ). Belgrade, Serbia: Singidunum University, Belgrade, Danijelova 32 Belgrade Serbia. Retrieved August 20, 2016, from http://portal.sinteza.singidunum. ac.rs/Media/files/2014/559-563.pdf. DOI: 10.15308/sinteza-2014-559-563.

Prichici, C., \& Ionescu, B.Ş. (2015). Cloud Accounting - A New Paradigm of Accounting Policies [Electronic version]. SEA Practical Application of Science. 3(7). 489-496. Retrieved August 20,2016, from http://sea.bxb.ro/Article/SEA_7_71.pdf.

Republički zavod za statistiku Republika Srbija. (2015). Upotreba informaciono-komunikacionih tehnologija u Republici Srbiji, Domaćinstva/Pojedinci/Preduzeća. 10-59. Retrieved August 20, 2016, from http://pod2.stat.gov.rs/ObjavljenePublikacije/G2015/pdf/G20156007.pdf.
Salesforce UK. (2015). Why Move To The Cloud? 10 Benefits Of Cloud Computing. Retrieved August 25, 2016, from https:// www.salesforce.com/uk/blog/2015/11/why-move-to-thecloud-10-benefits-of-cloud-computing.html

Savić, M., \& Janković, S. (2015). The Use of Cloud Computing in Accounting. In: Synthesis 2015 - International Scientific Conference of IT and Business-Related Research, 16-17 April 2015 (pp. 719-722). Belgrade: Singidunum University. Retrieved August 05, 2016, from http://portal.sinteza.singidunum.ac.rs/Media/files/2015/719-722.pdf. DOI: 10.15308/ Synthesis-2015-719-722.

The Cloud Accounting Institute. (2014). Cloud Accounting Soultions Best Practices. 2014 Benchmark Study. 1-11. Retrieved August 17, 2016, from http://www.armaninollp.com/ /media/pdf/benchmark-studies/cloud-solutions-best-practices2014-benchmark-study.ashx.

Valpovština Info. (2016). ARIOS - Agencija za računovodstvo, informatiku, organizaciju i savjetovanje, Dvadeset godina uspješnog poslovanja. Retrieved August 21, 2016, from http://www.arios.net/store/val-info-12.pdf.

Večernji list. (2016). Zaključao datoteke na računalu tvrtke pa tražio plaćanje u Bitcoinima. Retrieved August 21, 2016, from http://www.mnovine.hr/vijesti/hrvatska/crna/zakljucao-datoteke-na-racunalu-tvtke-pa-trazio-placanje-u-bitcoinima-.

Vićentijević, K., Petrović, Z., Jović, Z., Glišović, N., Rakočević, S., \& Kaljević, J. (2015). The use of Cloud Accounting Vs. Traditional Accounting in the Republic of Serbia. In: Synthesis 2015 - International Scientific Conference of IT and Business-Related Research, 16-17 April 2015 (pp. 711-714). Belgrade: Singidunum University. Retrieved August 15, 2016, from http://portal.sinteza.singidunum.ac.rs/ Media/files/2015/711-714.pdf. DOI: 10.15308/Synthesis-2015-711-714.

Zavod za statistiku Crne Gore. (2015). Upotreba informacionokomunikacionih tehnologija u preduzećima u Crnoj Gori 2015. godine. Saopštenje. (229), 1-7. Retrieved August 21, 2016, from https://www.google.nl/url?sa=t\&rct=j\&q=\&esr $\mathrm{c}=\mathrm{s} \&$ source $=$ web\&cd $=1$ \&ved $=0 \mathrm{ahUKEwj} 6 \mathrm{r} 6 \mathrm{mFsfbOAhV}$ BoBQKHRxcAJkQFggcMAA\&url=http\%3A\%2F\%2Fwww. mid.gov.me\%2FResourceManager\%2FFileDownload.aspx \%3FrId\%3D219024\%26rType\%3D2\&usg=AFQjCNHMV HX3Ud6tQk4bvyS6ECKJ96Z8qw\&sig2=Qg3Ol984NbZd IU_QfU_bdg\&bvm=bv.131783435,d.d24\&cad=rja.

\section{CLOUD ACCOUNTING IN THE REPUBLIC OF CROATIA}

\begin{abstract}
:
Cloud accounting proposes a leap forward from the traditional accounting system towards the new system supported by information technology. Advantages of cloud accounting in comparison with traditional accounting are numerous, although some disadvantages are present as well. The objective of this paper is to research the awareness of cloud accounting usage in the Republic of Croatia as well as the degree of risk associated with entrusting third parties with business data, offering cloud services. The hypothesis suggests that accountants in the Croatian Republic are not well informed either about the advantages of cloud accounting or the ways in which cloud accounting can affect business organizations. An online survey was carried out in order to prove the proposed hypothesis which mainly focused on the group consisting of accountants and future accountants, students of The Faculty of Economics situated in a Croatian city. This paper concludes with recommendations on increasing cloud accounting awareness in Croatia, Serbia and Bosnia and Herzegovina.
\end{abstract}

\section{Keywords:}

information technology, cloud computing, traditional accounting, benefits, advantages. 